\title{
KINETICS OF THE NON-ISOTHERMAL DESORPTION OF ETHANOL ABSORBED ONTO CMS-3A
}

\author{
Nikola S. Jovančića , Borivoj K. Adnađevićb, Jelena D. \\ Jovanovićc \\ University of Belgrade, Faculty of Physical Chemistry, Belgrade, \\ Republic of Serbia \\ a e-mail: nikola.jovancic82@gmail.com, \\ ORCID iD: (Dhttp://orcid.org/0000-0003-4917-9104 \\ b e-mail: bora@ffh.bg.ac.rs, \\ ORCID iD: 10http://orcid.org/0000-0002-9555-8191 \\ c e-mail: jelenaj@ffh.bg.ac.rs, \\ ORCID iD: (i)http://orcid.org/0000-0002-7537-9591
}

https://dx.doi.org/10.5937/vojtehg65-12187

FIELD: Chemical Technology

ARTICLE TYPE: Original Scientific Paper

ARTICLE LANGUAGE: English

\section{Abstract:}

The kinetics of the desorption of ethanol previously absorbed onto carbon molecular sieves (CMS-3A) was studied using the non-isothermal thermogravimetric technique. The dependence of activation energy $\left(E_{a, a}\right)$ for a particular degree of desorption ( $\alpha$ ) was established. It was confirmed that the non-isothermal desorption of ethanol was a kinetically complex process. A novel mathematical model for the kinetics of non-isothermal desorption for the absorbed ethanol is established. This model is based on the proposed dependence of the specific desorption rate on time/temperature. The correlation dependences of the model parameters $\beta$ and $\eta$ on heating rates were established. A general kinetic equation for the non-isothermal desorption of ethanol was developed. It was found that the specific desorption rate at every single heating rate increases, whereas $E_{a}$, decreases during the desorption process.

Key words: dependant, absorbers, molecular sieves, analytical models, model, zeolites, CMS-3A, kinetics, ethanol, desorption.

ACKNOWLEDGEMENT: This investigation was supported by the Ministry of Science and Technical Development of the Republic of Serbia through Project 172015 OI. 


\section{Introduction}

Bioethanol nowadays presents a main alternative source for the economic production of novel fuels and ethanol (Kosaric, et al, 2001). Ethanol is produced by fermentation of sugars obtained by hydrolyses of biomass. Three sources of biomass are commonly used: sugar, corn and lignocellulose materials. The most promising source is the lignocellulose biomass because it can use agricultural and forest residues and prevent the heated fuel-versus-food debate (Hashi, et al, 2010, pp.4628-4637). The only barrier for a broad application of production of ethanol is a high production cost (Kaminski, et al, 2008, pp.95-102).

Produced bioethanol contains a certain amount of water. The distillation process used for bioethanol separation and purification requires a large amount of energy which is approximately equal to $50 \%$ of the combustion energy of produced bioethanol (Fujita, et al, 2011, pp.869879). Selective ethanol adsorption on a hydrophobic material of the zeolite type is a way to reduce the energy consumption of this process, presently the most promising procedure for an energetically rational bioethanol production (Adnadjevic, Jovanovic, 2012, pp.761-768). The introduction of this new separation process for bioethanol production requires solving a novel problem of cheep and effective selective procedure of adsorbed ethanol desorption onto a zeolite type adsorbent. The key role in this solution is in the kinetics of ethanol desorption from the zeolite adsorbent. It was shown that the most effective adsorbents are carbon molecular sieves such as CMS - 3A. Knowing the kinetics of ethanol desorption can contribute to better and more economical production of bioethanol. Unfortunately, to the best of our knowledge, the literature data is sparse with data concerning this topic.

Fujita and co-workers investigated the kinetics of desorption of ethanol and water from various types of commercial zeolite (MSC-3A, 4A, $-5 \mathrm{~A},-6 \mathrm{~A},-7 \mathrm{~A}$, HiSiV3000, ZSM-5 (Si02/AI03 =30), hydrophilic 5A) in the gaseous phase and evaluated the effectiveness of the proposed process (Fujita, et al, 2011, pp.869-879). The desorption of 1-buthanol from water solution adsorbed onto ZSM-5 with a high Si/Al ratio was discussed in the work of Saravanan et al. (Saravanan, et al, 2010, pp.68-69). Oudshoorn et al. investigated the desorption rate of 1- buthanol from zeolite CVB28014, CVB901 (Oudshoorn, et al, 2012, pp.167-172).

Keeping that in mind, this work thoroughly investigates the kinetics of the non-isothermal desoprption of ethanol adsorbed onto carbon molecular 
sieves (CMS-3A). Therefore, a kinetic model, kinetic complexity and the values of the kinetics parameters were determined and discussed.

\section{Materials and Methods}

\section{Materials}

The following materials were used: a carbon molecular sieve type $3 \mathrm{~A}$ (CMS-3A), produced by Takeda Chem. Ind., Japan; ethanol 99.8 vol. \% of p.a. purity purchased from Hemos, Belgrade, Serbia, and bidistilled water obtained from Hemofarm, Serbia. Before use, the CMS-3A was thermally activated at a temperature of $393 \mathrm{~K}$ for 2 hours, cooled and kept in a dessicator until use.

\section{Characterization}

The texture properties of the activated sample used were determined by N2 $(77 \mathrm{~K})$ adsorption using a Micrometrics ASAP 2010 volumetric adsorption apparatus. The BET surface area was measured from the adsorption isotherms by applying the Brunauer-Emmett-Teller equation to calculate the micropore volume $\left(V_{m p}\right)$. The total volume $\left(V_{t}\right)$ was obtained at a relative pressure of 0.99 . The pore size distribution (PSD) was obtained by the Horvath-Kawazoe analysis.

\section{Sample preparation}

Ethanol was absorbed onto the CMS-3A as follows. One gram of thermally activated CMS-3A was added to $50 \mathrm{~mL}$ of ethanol. Ethanol adsorption was undertaken for 24 hours. The ethanol adsorbed-CMS (CMSethanol) sample was separated from the ethanol excess by decantation. The sample was kept in the exicator to prevent ethanol desorption.

\section{Thermogravimetric measurements}

The non-isothermal thermogravimetric curves were recorded using a TA Instruments SDT simultaneous TGA-DSC thermal analyzer, model 2960. These experiments were performed with the CMS-ethanol absorbed 
samples weighing $20 \pm 5 \mathrm{mg}$. The samples were placed in the platinum pans under (99.9995 vol. \%) nitrogen flowing at a rate of $20 \mathrm{~mL} \mathrm{~min}^{-1}$. Four different heating rates $\left(v_{h}=5,10,15\right.$ and $\left.20 \mathrm{~K} \mathrm{~min}^{-1}\right)$ were used in this study. All experiments in this work were conducted in the temperature range from ambient temperature up to $400 \mathrm{~K}$. For isothermal methods, it is necessary that the process of desorption is performed at a lower temperature range from ambient to $500 \mathrm{~K}$. The original mass loss versus temperature (TG) curves obtained at a constant heating rate were transformed into the degree of desorption $(\alpha)$ versus temperature curves by means of the following equation:

$$
\alpha=\frac{m_{0}-m}{m_{0}-m_{f}}
$$

where $m_{0}, m$ and $m_{f}$ refer to the initial, actual and final mass of the sample.

\section{Kissinger-Akahira-Sunose (KAS) method}

The Kissinger-Akahira-Sunose method (Akahira, Sunose, 1971, pp.22-31) is the isoconversional integral method which uses CoatsRedfern approximation (Coats, Redfern, 1964, pp.1273-1278) of the temperature integral that leads to the equation:

$$
\ln \left(\frac{v_{h}}{T^{2}}\right)=\ln \left(\frac{A R}{E_{a} g(\alpha)}\right)-\frac{E_{a}}{R T}
$$

where $g(\alpha)$ is the integral form of the selected kinetic model. For $\alpha=$ const., the plot of $\ln \left(v_{h} / T^{2}\right) v s \cdot T^{-1}$ should be a straight line the slope of which can be used to evaluate the apparent activation energy.

\section{Kinetic model}

\section{Desorption kinetics model}

The ethanol desorption process is affected by many parameters such as temperature, time, pressure, ethanol concentration, $\mathrm{pH}$ of the solution, as well as the structural characteristics of carbon molecular sieves. The mathematical models of desorption presented bellow are based on the following assumptions listed below: (a) The desorption process is a kinetically complex process; (b) Leaving the molecules of a certain part of 
the absorbed phase (desorption) leads to structural changes in the absorbed phase and its nearby surroundings (structural rearrangement); (c) The desorption rate is significantly higher than the structural rearrangement rate; (d) As a consequence of the above, the specific desorption rate $(k)$ is a function of both time $(t)$ and temperature $(T)$, which can be described by the equation:

$$
k=\frac{\beta}{\eta}\left(\frac{t}{\eta}\right)^{\beta-1}
$$

i.e

$$
k=\frac{\beta}{\eta}\left(\frac{T-T_{0}}{v_{h} \eta}\right)^{\beta-1}
$$

where $\beta$ and $\eta$ are the Weibull's parameters, To is the initial temperature and $\mathrm{vh}$ is the heating rate; (e) the rate of desorption $(d N / d t)$ is proportional to the amount of the remaining molecules in the adsorbed phase. In this case, the desorption rate is given as:

$$
\frac{d N}{d T}=\frac{k}{v_{h}}\left(N_{0}-N\right)
$$

where $N_{0}$ is the amount of the adsorbed molecules in the beginning of the desorption process, and $N$ is the amount of the desorbed molecules at $T$. Introducing Eq (4) into Eq (5) yields:

$$
\frac{d N}{d T}=\frac{\beta}{v_{h} \eta}\left(\frac{T-T_{0}}{v_{h} \eta}\right)^{\beta-1}\left(N_{0}-N\right)
$$

The separation of the variables in equation (3) leads to:

$$
\int_{0}^{N} \frac{d N}{\left(N_{0}-N\right)}=\int_{0}^{T} \frac{\beta}{v_{h} \eta}\left(\frac{T-T_{0}}{v_{h} \eta}\right)^{\beta-1} d T
$$

The integration of equation (7) should be done in the limits of $\mathrm{N}$ from 0 to $\mathrm{N}$ and of $\mathrm{T}$ from To to $\mathrm{T}$, to yield:

$$
\ln \left(\frac{N_{0}-N}{N_{0}}\right)=\left(\frac{T-T_{0}}{v_{h} \eta}\right)^{\beta}
$$


The results is:

$$
\frac{N_{0}-N}{N_{0}}=\exp \left[-\left(\frac{T-T_{0}}{v_{h} \eta}\right)\right]^{\beta}
$$

Since: $\alpha=N / N_{0}$, equation (9) is transformed into the form:

$$
\alpha=1-\exp \left[-\left(\frac{T-T_{0}}{v_{h} \eta}\right)\right]^{\beta}
$$

\section{Results and discussion}

Figure 1 shows the thermogravimetric curves for the desorption of ethanol from CMS at various heating rates.

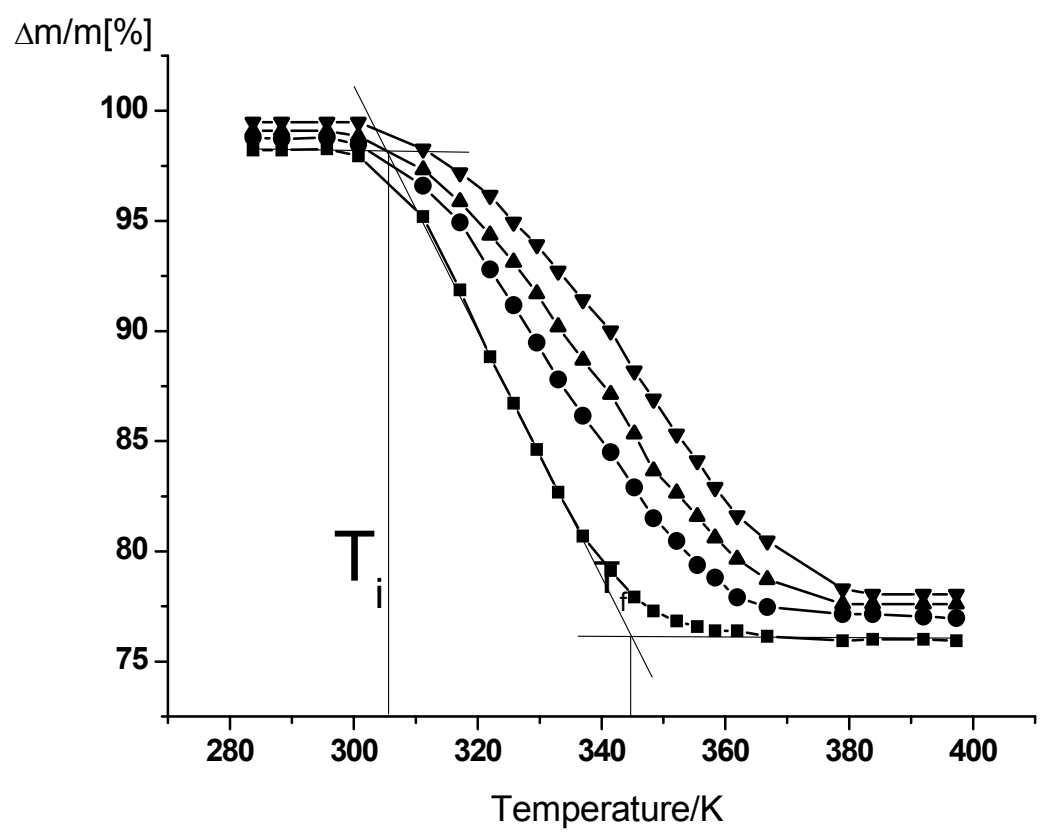

Figure 1 - The TG curves for the desorption of ethanol from CMS at various heating rates: $5 \mathrm{Kmin}^{-1}, \bullet-10 \mathrm{Kmin}^{-1} \boldsymbol{\Delta}-15 \mathrm{Kmin}^{-1} \boldsymbol{\nabla}-20 \mathrm{Kmin}^{-1}$

Puc. 1 - TG кривая десорбции этанола с CMS при разных скоростях нагревания: $5 \mathrm{~K}$ мин-1, •- $10 \mathrm{~K}$ мин-1 $\boldsymbol{\Delta}-15 \mathrm{~K}$ мин-1 $\boldsymbol{\nabla}-20 \mathrm{~K}$ мин-1

Слика 1 - TG крива десорпције етанола са CMS на различитим брзинама загревања: $5 \mathrm{Kmin}^{-1}, \bullet-10 \mathrm{Kmin}^{-1} \Delta-15 \mathrm{Kmin}^{-1} \nabla-20 \mathrm{Kmin}^{-1}$ 
As it can be seen from Figure 1, the TG curves for the desorption of ethanol at all investigated heating rates are of a complex sigmoid shape. As it is obvious from the TG curves, both the initial temperature $\left(T_{i}\right)$ and the final temperature $\left(T_{f}\right)$, the reaction interval $\left(\Delta T=T_{f}-T_{i}\right)$ and the degree of asymmetry of the curves change with the change in the heating rates. Table 1 summarizes the effects of heating rates on the values of $T_{i}$, $T_{f} \Delta T$ and the residual $(\Delta m / m)$.

Table 1 - Data for the heating rates, initial temperatures, final temperatures, reaction intervals and percentage of residual masses for Fig.1

Таблица 1 - Значения температуры в начале десорбции, при завершении десорбции, температурного интервала и остаток массы в процентах

Табела 1 - Вредности температуре почетка десорпције, температуре завршетка десорпције, температурског интервала и процентни остатак масе

\begin{tabular}{|c|c|c|c|c|}
\hline$v_{h}[\mathrm{~K} / \mathrm{min}]$ & $T_{i}[\mathrm{~K}]$ & $T_{f}[\mathrm{~K}]$ & $\Delta T[\mathrm{~K}]$ & $\Delta m / m[\%]$ \\
\hline 5 & 305.63 & 344.59 & 38.96 & 76.04 \\
\hline 10 & 308.09 & 358.63 & 50.54 & 76.97 \\
\hline 15 & 310.54 & 366.65 & 56.11 & 77.72 \\
\hline 20 & 312.29 & 373.73 & 61.44 & 78.02 \\
\hline
\end{tabular}

As it is obvious from the results presented in Table 1, the increase of the heating rate leads to the increase in the values of $T_{i}, T_{f}$ and $\Delta T$, where the residual insignificantly varies within the experimental error. In order to preliminary determine the kinetic model of ethanol desorption, the shape of the dependence $d \alpha / d t$ on $\alpha$ is analyzed. (Khawam, Flangan, 2005, pp.10073-10080). The dependence of $d \alpha / d t$ on $\alpha$ is presented in Figure 2.

The dependence of $d \alpha / d t$ on $\alpha$ shows a broad asymmetric peak with a clear maximum $-\alpha_{\max }$. With the increase of the heating rate, the value of $\alpha_{\max }$ increases almost linearly. Since the dependence of $d \alpha / d t$ on $\alpha$ has a complex shape, the dependence of $E_{a, \alpha}$ on $\alpha$ is determined by applying the KAS method. The dependence of $E_{a, \alpha}$ on $\alpha$ is shown in Figure 3. 


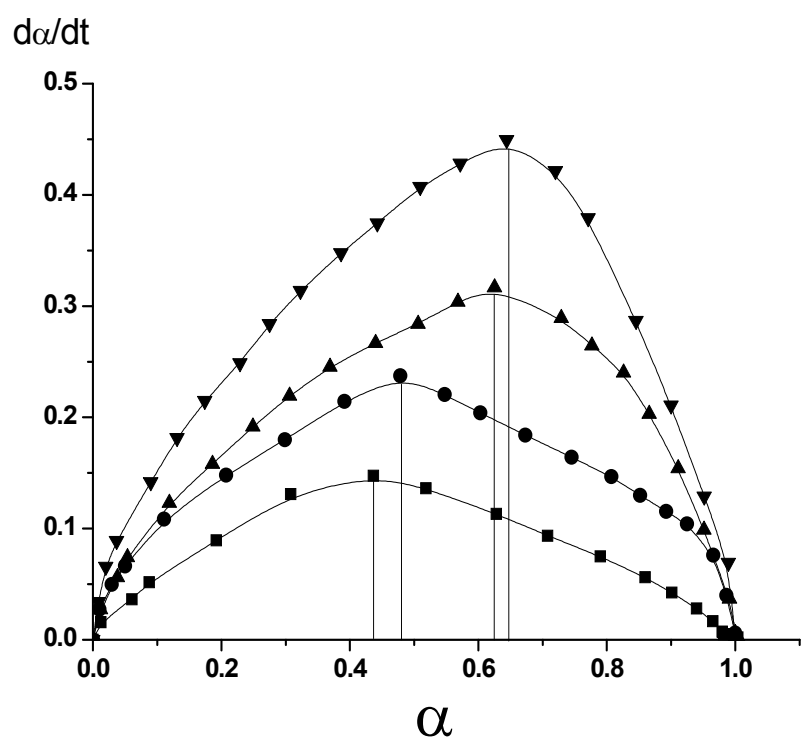

Figure 2 - The dependence of $d \alpha / d t$ on $\alpha$ at various heating rates:

- $5 \mathrm{~K} \mathrm{~min}^{-1}, \bullet-10 \mathrm{~K} \mathrm{~min}^{-1} \boldsymbol{\Delta}-15 \mathrm{~K} \mathrm{~min}^{-1} \boldsymbol{\nabla}-20 \mathrm{~K} \mathrm{~min}^{-1}$

Puc. 2 - зависимость $d \alpha / d t$ при разных скоростях нагревания:

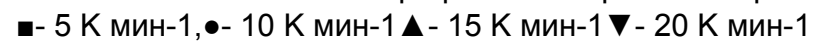

Слика 2 - зависност $d \alpha / d t$ на различитим брзинама загревања:

- $5 \mathrm{~K} \mathrm{~min}^{-1}, \bullet-10 \mathrm{~K} \mathrm{~min}^{-1} \boldsymbol{\Delta}-15 \mathrm{~K} \mathrm{~min}^{-1} \boldsymbol{\nabla}-20 \mathrm{~K} \mathrm{~min}^{-1}$

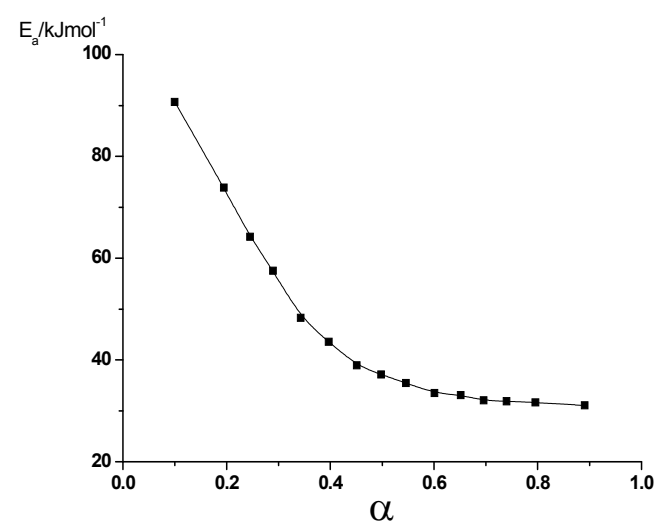

Figure 3-The dependence of $E_{a, \alpha}$ on $\alpha$

Pис. 3 - Зависимость $E_{a, \alpha}$ от $\alpha$

Слика 3 - зависност $E_{a, \alpha}$ od $\alpha$ 
The values of $E_{a, \alpha}$ decrease with the increase in the values of $\alpha$. The analysis of the shape of the dependence of $E_{a, \alpha}$ on $\alpha$ clearly reveals two characteristic shapes of changes in $E_{a, \alpha}$ with the increasing $\alpha$. In the range of $0 \leq \alpha \leq 0.25, E_{a, \alpha}$ decreases almost linearly with increasing the $\alpha$ values from $\sim 100 \mathrm{~kJ} \mathrm{~mol}^{-1}$ to $\sim 60 \mathrm{~kJ} \mathrm{~mol}^{-1}$. In contrast to this, when $\alpha \geq 0.25$, the increase of $\alpha$ leads to concave decrease in the value $E_{a, \alpha}$ from $\sim 60 \mathrm{~kJ}$ $\mathrm{mol}^{-1}$ to $\sim 20 \mathrm{~kJ} \mathrm{~mol}^{-1}$. A complex shape of the dependence of $E_{a, \alpha}$ on $\alpha$, in accordance with Vyazovkin's criteria (Vyazovkin, Linert, 1995, pp.109-118), indicates that the process of desorption of the ethanol from the CMS is a kinetics complex process which takes place through numerous elementary stages. In regard to that, the ability of a mathematical description of the kinetics of ethanol desorption with equation (10) was evaluated. Figure 4 presents the dependence of $\ln [-\ln (1-\alpha)]$ on $\ln \left[\frac{T-T_{0}}{v_{h}}\right]$ at different heating rates.

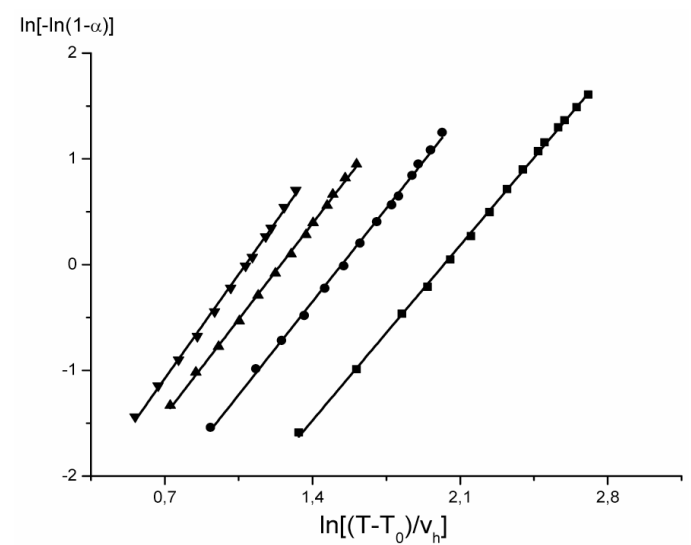

Figure 4-Dependence of $\ln [-\ln (1-\alpha)]$ on $\ln \left[\frac{T-T_{0}}{v_{h}}\right]$ at different heating rates:

- $5 \mathrm{~K}$ min-1, •- $10 \mathrm{~K}$ min-1 $\boldsymbol{\Delta}-15 \mathrm{~K}$ min-1 $\boldsymbol{\nabla}-20 \mathrm{~K}$ min-1

Puc. 4 - Зависимость $\ln [-\ln (1-\alpha)]$ от $\ln \left[\frac{T-T_{0}}{v_{h}}\right]$ при разных скоростях нагревания:

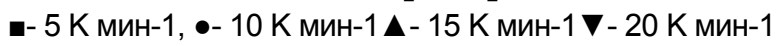

Слика 4- Зависност $\ln [-\ln (1-\alpha)]$ од $\ln \left[\frac{T-T_{0}}{v_{h}}\right]$ на различитим брзинама загревања:

- $5 \mathrm{~K}$ min-1, •- $10 \mathrm{~K}$ min-1 $\boldsymbol{\Delta}-15 \mathrm{~K}$ min-1 $\boldsymbol{\nabla}-20 \mathrm{~K}$ min-1 
Table 2 - Values of the Weibull's parameters at different heating rates

Таблица 2 - Значения параметров Вейбулла при разных скоростях нагревания Табела 2 - Вредности Вејбулових параметара на различитим брзинама загревања

\begin{tabular}{|l|l|l|}
\hline$v_{h}[\mathrm{~K} / \mathrm{min}]$ & $\beta$ & $\eta[\mathrm{min}]$ \\
\hline 5 & 2.35 & 7.57 \\
\hline 10 & 2.47 & 4.69 \\
\hline 15 & 2.63 & 3.47 \\
\hline 20 & 2.82 & 2.95 \\
\hline
\end{tabular}

Obviously, the dependencies of $\ln [-\ln (1-\alpha)]$ on $\ln \left[\frac{T-T_{0}}{v_{h}}\right]$ for all of the investigated heating rates are linear. The values of the parameters $\beta$ and $\eta$ were calculated based on the slopes and intercepts the dependencies of $\ln [-\ln (1-\alpha)]$ on $\ln \left[\frac{T-T_{0}}{v_{h}}\right]$. The effect of heating rates on the Weibull's parameters $\beta$ and $\eta$ is shown in Table 2 .

As it can be seen from the results presented in Table 3 , the increase in the heating rates leads to the increase in the values of the parameter $\beta$ while the values of the parameter $\eta$ decrease. The found changes in the values of the parameters $\beta$ and $\eta$ can be mathematically described by the expressions:

$$
\begin{aligned}
& \beta\left(v_{h}\right)=\exp \left(0.827+0.05 v_{h}+0.0003 v_{h}^{2}\right) \\
& \eta\left(v_{h}\right)=\exp \left(2.658-0.143 v_{h}+0.003 v_{h}^{2}\right)
\end{aligned}
$$

The mathematical expressions (11) and (12) enable to derive an equation which can successfully describe the kinetics of the investigated process as a function of temperature and heating rates:

$$
\frac{d \alpha}{d T}=\frac{\beta\left(v_{h}\right)}{v_{h} \eta\left(v_{h}\right)}\left[\frac{\left(T-T_{0}\right)}{v_{h} \eta\left(v_{h}\right)}\right]^{\beta\left(v_{h}-1\right)} \exp \left[-\left(\frac{T-T_{0}}{v_{h} \eta\left(v_{h}\right)}\right)^{\beta\left(v_{h}\right)}\right]
$$

Based on the knowledge on the values of the parameters $\beta$ and $\eta$ by using Eq (4), it is possible to calculate the values of a specific desorption rate for different temperatures at different heating rates. Figure 5 pre- 
sents the dependence of the specific desorption rate with temperatures for different heating rates.

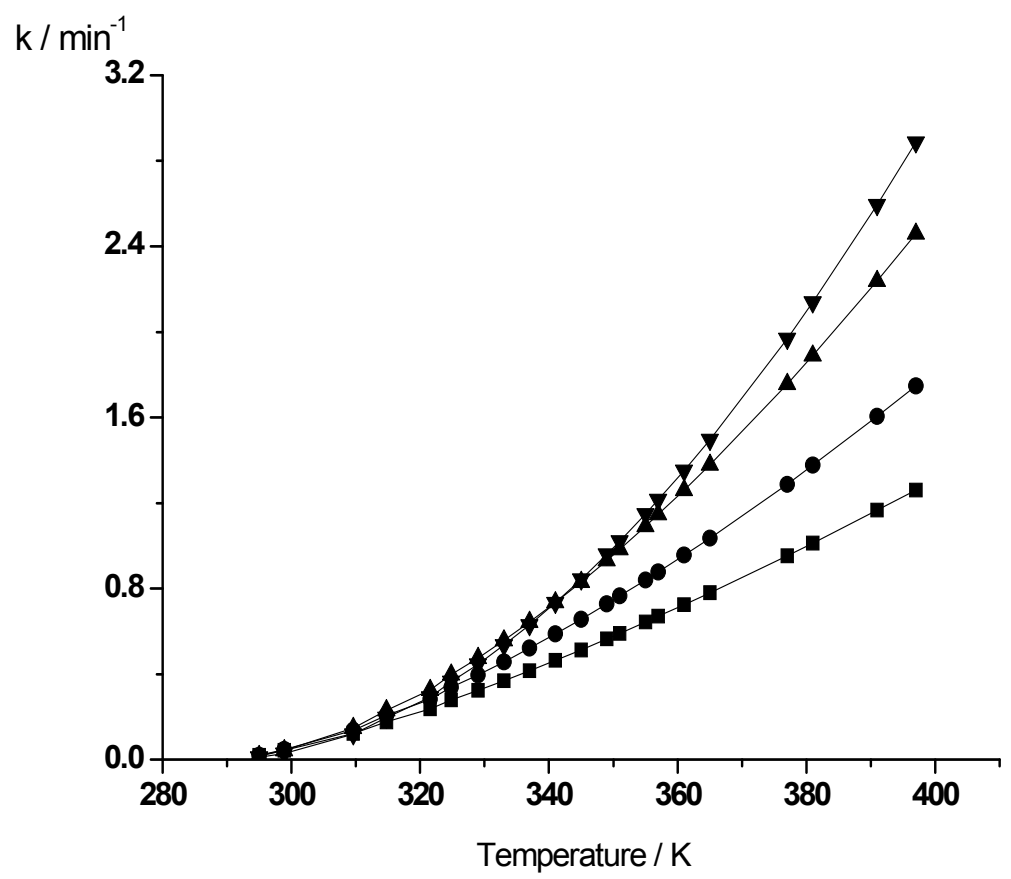

Figure 5-Dependence of $\mathrm{k}$ on temperature at different heating rates:

$$
\text { - } 5 \mathrm{~K} \mathrm{~min}^{-1}, \bullet-10 \mathrm{~K} \mathrm{~min}^{-1} \boldsymbol{\Delta}-15 \mathrm{~K} \mathrm{~min}^{-1} \boldsymbol{\nabla}-20 \mathrm{~K} \mathrm{~min}^{-1}
$$

Puc. 5 - Зависимость k от температуры при различных скоростях нагревания - $5 \mathrm{~K} \mathrm{мин}^{-1}, \bullet-10 \mathrm{~K} \mathrm{мин}^{-1} \boldsymbol{\Delta}-15 \mathrm{~K} \mathrm{мин}^{-1} \boldsymbol{\nabla}-20 \mathrm{~K} \mathrm{мин}^{-1}$

Слика 5 - Зависност $\mathrm{k}$ од температуре на различитим брзинама загревања - $5 \mathrm{~K} \mathrm{~min}^{-1}, \bullet-10 \mathrm{~K} \mathrm{~min}^{-1} \Delta-15 \mathrm{~K} \mathrm{~min}^{-1} \boldsymbol{\nabla}-20 \mathrm{~K} \mathrm{~min}^{-1}$

The increase in temperature leads to the increase in the values of the specific desorption rate at all of the investigated heating rates. Also, the increase in the heating rates at all investigated temperature values leads to the increase in the values of the specific desorption rate. The established dependencies of $k$ on $T$ allow applying the Arrhenius equation to calculate the values of activation energies at different temperatures for different heating rates. The dependence of $E_{a}$ on temperature at the investigated heating rates is presented in Figure 6. 


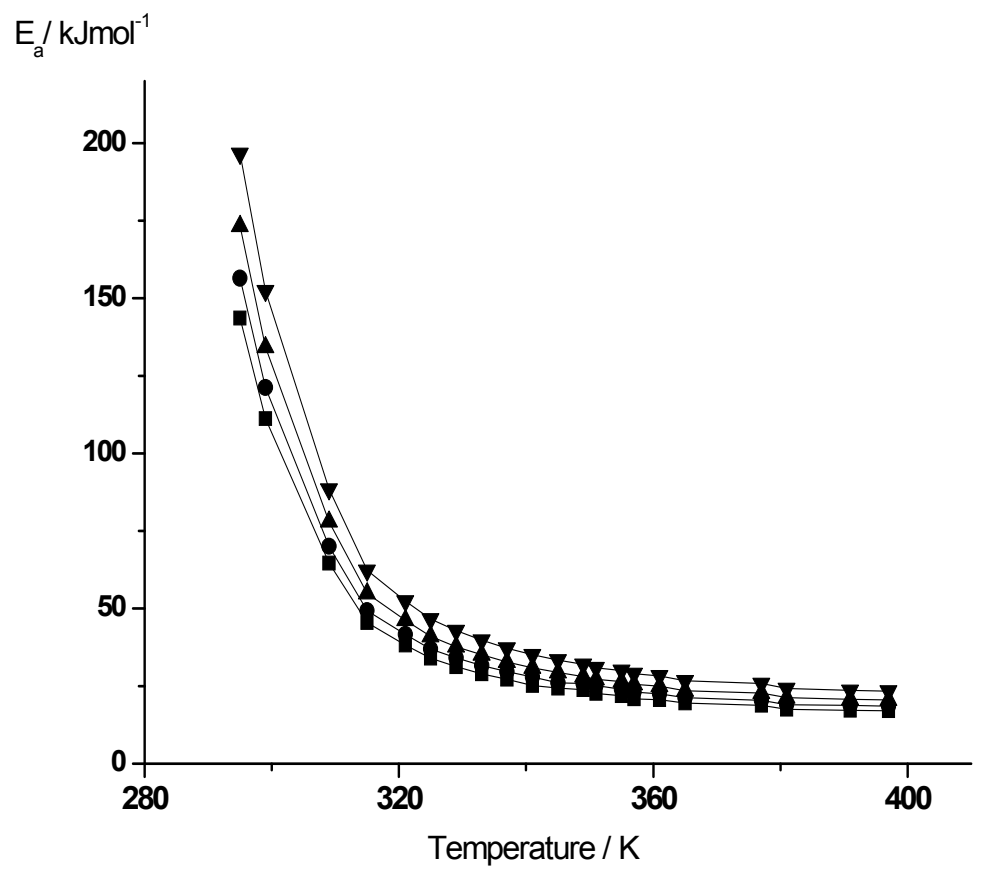

Figure 6 - The dependence of $E_{a}$ on temperature at different heating rates: - $5 \mathrm{~K} \mathrm{~min}^{-1}, \bullet-10 \mathrm{Kmin}^{-1} \Delta-15 \mathrm{~K} \mathrm{~min}^{-1} \boldsymbol{\nabla}-20 \mathrm{~K} \mathrm{~min}^{-1}$

Puc. 6 - Зависимость $E_{a}$ от температуры при различных скоростях нагревания - $5 \mathrm{~K} \mathrm{мин}^{-1}, \bullet-10 \mathrm{~K}$ мин $^{-1} \boldsymbol{\Delta}-15 \mathrm{~K}$ мин $^{-1} \boldsymbol{\nabla}-20 \mathrm{~K}$ мин $^{-1}$

Слика 6 - Зависност $E_{a}$ од температуре на различитим брзинама загревања: - $5 \mathrm{~K} \mathrm{~min}^{-1}, \bullet-10 \mathrm{Kmin}^{-1} \Delta-15 \mathrm{~K} \mathrm{~min}^{-1} \boldsymbol{\nabla}-20 \mathrm{~K} \mathrm{~min}^{-1}$

The $E_{a}$ value decreases with the increasing temperature at all of the investigated heating rates. The two characteristic shapes of changes of $E_{a, T}$ with increasing $T$ are obvious. In the range of $290 \leq T \leq 315 \mathrm{~K}$, the dependence $E_{a, T}$ on $T$ almost linearly decreases with increasing temperature, whereas at temperatures $315 \leq T \leq 400 \mathrm{~K}$, the value of $E_{a}$ decreases concavely with increasing temperature. At a particular value of temperature, the value of $E_{a}$ increases with the increase in the heating rate. Based on the dependence of $E_{a}$ on temperature at a particular heating rate, it is 
possible to get the dependence of $E_{a, \alpha}$ on $\alpha$ for that heating rate. Figure 7 presents the dependence of $E_{a, \alpha}$ on $\alpha$ for different heating rates.

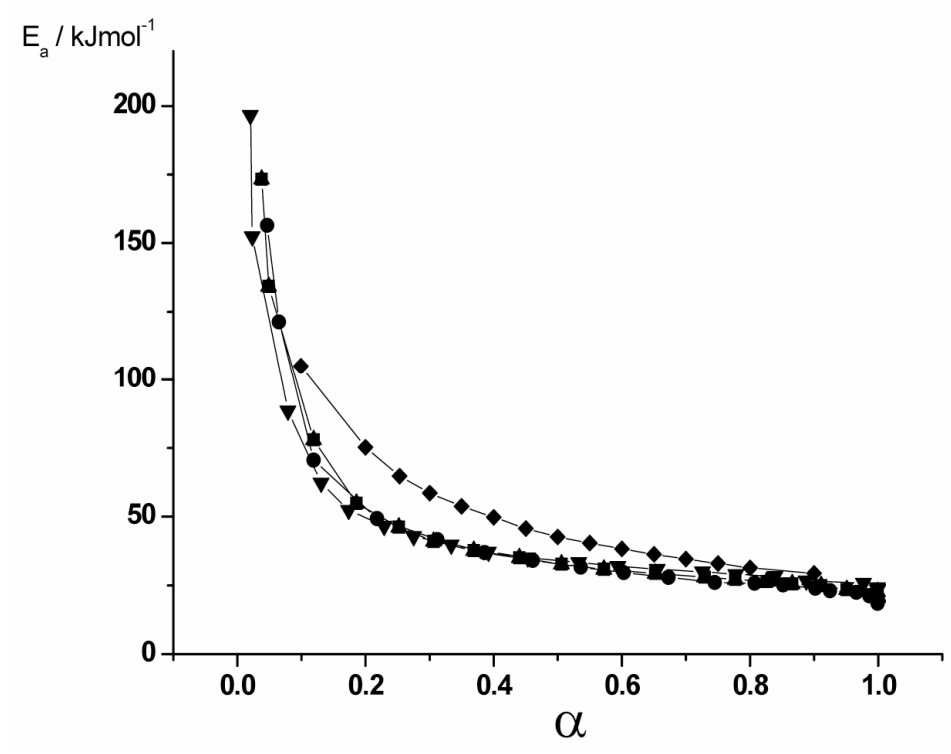

Figure 7 - Dependence of $E_{a, \alpha}$ on $\alpha$ for different heating rates

Pис. 7 - Зависимость $E_{a}$ от $\alpha$ при различных скоростях нагревания

Слика 7 - Зависност $E_{a, \alpha}$ од $\alpha$ на различитим брзинама загревања

The curves of the dependence of $E_{a, \alpha}$ on $\alpha$ at all investigated heating rates are of similar shapes. The curves of the dependence of $E_{a, \alpha}$ on $\alpha$ show two different shapes of changes of the dependence of $E_{a, \alpha}$ on $\alpha$. The two characteristic shapes of changes of $E_{a, \alpha}$ with increasing $\alpha$ are obvious. For the range of values $0 \leq \alpha \leq 0.2$, the dependence $E_{a, \alpha}$ on $\alpha$ linearly decreases with increasing $\alpha$. For the values of $\alpha>0.2$, the values of $E_{a, \alpha}$ decrease concavely with increasing $E_{a, \alpha}$. The comparison of the shapes of the dependences of $E_{a}$ on $\alpha$ at different heating rates with the dependence of $E_{a, \alpha}$ on $\alpha$ obtained by the isoconversion method (Fig 3 ) clearly shows their mutual similarity, especially at extremely low and high degrees of desorption. The found similarity confirms physical reality of the previously suggested model for the non-isothermal desorption based on the assumption about the changes in the values of the specific rate of 
desorption with temperature. Since with the increasing temperature the specific rate of desorption increases more rapidly than the rate of internal rearrangement of ethanol's molecules in the absorbed phase, the activation energy decreases, the kinetics complexity changes and the specific rate of desorption increases.

\section{Conclusion}

The non-isothermal desorption of ethanol absorbed onto CMS-3A is a kinetically complex process. Kinetic's complexity of the desorption of ethanol is a consequence of the changes in the specific rate of desorption and activation energy with temperature. The conversion kinetics curves of the non-isothermal desorption of ethanol, at all heating rates, can be entirely mathematically described by the suggested model. The correlation dependences of the parameters of the kinetics model on heating rates are established. A general kinetics equation of the non-isothermal desorption of ethanol is developed. It was found that the value of the specific desorption rate of ethanol, at every single heating rate, increases with the increase in temperature, whereas the activation energy decreases. The functional dependences of activation energy on time for each heating rate were determined. The results obtained by this work can be used to enhance the knowledge of the desorption kinetics of ethanol, wich is a key factor for its more economical production.

\section{Symbols}

$\begin{array}{ll}E_{a}\left[\mathrm{~kJ} \mathrm{~mol}^{-1}\right] & \begin{array}{l}\text { activation energy } \\ E_{a, \alpha}\left[\mathrm{kJ} \mathrm{mol}^{-1}\right]\end{array} \\ E_{a, T}\left[\mathrm{~kJ} \mathrm{~mol}^{-1}\right] & \text { activation energy at } \alpha \\ V_{m p} \mathrm{Vmp}^{2}\left[\mathrm{~cm}^{3} \mathrm{~g}^{-1}\right] & \begin{array}{l}\text { mictivation energy at } T \\ V_{t}\left[\mathrm{~cm}^{3} \mathrm{~g}^{-1}\right]\end{array} \\ d[\mathrm{~nm}] & \text { total volume } \\ m_{0}[\mathrm{~g}] & \text { average pore size } \\ m[\mathrm{~g}] & \text { the initial mass of the sample } \\ m_{f}[\mathrm{~g}] & \text { actual mass of the sample } \\ \Delta m / m[\%] & \text { final mass of the sample } \\ g(\alpha) & \text { percentage of residual mass } \\ & \text { integral form of the selected }\end{array}$


$T[\mathrm{~K}]$

$T^{-1}\left[\mathrm{~K}^{-1}\right]$

$T_{i}[\mathrm{~K}]$

$T_{f}[\mathrm{~K}]$

$\Delta T[\mathrm{~K}]$

$R\left[\mathrm{~J} \mathrm{~mol}^{-1} \mathrm{~K}^{-1}\right]$

$k\left[\mathrm{~min}^{-1}\right]$

$t$ [min]

$T_{0}[\mathrm{~K}]$

$d N / d t$

$N_{0}$

$N$

$v_{h}\left[\mathrm{~K} \mathrm{~min}^{-1}\right]$

Greek symbols

$\alpha \propto \alpha[-]$

$\alpha_{\text {max }}[-]$

$\beta[-]$

$\eta$ [min]

Abbreviations

CMS-3A

CMS-ethanol

PSD

TG

KAS method

MSC-3A

MSC-4A

MSC -5A

MSC -6A

MSC -7A

HiSiV3000

ZSM-5

CVB28014

CVB901 temperature

inverse temperature

initial temperature at TG

final temperature at TG

reaction interval

universal gas constant (8.314)

specific desorption rate

time

initial temperature

rate of desorption

amount of the adsorbed

molecules in the beginning

of the desorption process

amount of the desorbed molecules at temperature

heating rate

degree of desorption

maximum degree of desorption

Weibull's parameter

Weibull's parameter

Carbon molecular sieves type 3A

Ethanol adsorbed carbon molecular sieves

Pore size distribution

Thermogravimetric curve

Kissinger-Akahira-Sunose method

Molecular Sieving Carbon type 3A

Molecular Sieving Carbon type 4A

Molecular Sieving Carbon type 5A

Molecular Sieving Carbon type 6A

Molecular Sieving Carbon type 7A

Silicalite zeolite

Zeolite Socony Mobil-5

Zeolite ammonium ZSM-5

Zeolite H-SDUSY 


\section{References}

Adnadjevic, B., \& Jovanovic, J., 2012. Kinetics of Isothermal Ethanol Adsorption onto a Carbon Molecular Sieves under Conventional and Microwave heating. Chemical Engineering Technology, 34(4), pp.761-768. Available at: http://dx.doi.org/10.1002/ceat.201100153.

Akahira, T., \& Sunose, T., 1971. Trans. Joint Convention of Four Electrical Institutes. Research Report, Chiba Institute of Technology, 16(246), pp.22-31.

Coats, A.W., \& Redfern, J.P.,1964. Kinetic Parameters from Thermogravimetric Data. Nature, 201(4914), pp.68-69. Available at: http://dx.doi.org/10.1038/201068a0.

Fujita, H., Qian, Q., Fujii, T., Moschizuki, K., \& Sakoda, A., 2011. Isolation of ethanol from its aqueous solution by liquid phase adsorption and gas phase desorption using molecular sieving carbon. Adsorption, 17, pp.869-879.

Hashi, M., Tezel, F.H., \& Thibault, J., 2010. Ethanol Recovery from Fermentation Broth via Carbon Dioxide Stripping and Desorption. Energy \& Fuels, 24(9), pp.4628-4637.

Kaminski, W., Marszalek, J., \& Ciolkowska, A., 2008. Renewable energy source: Dehydrated ethanol. The Chemical Engineering Journal, 135(1), pp.95102. Available at: http://dx.doi.org/10.1016/j.cej.2007.03.017.

Khawam, A., \& Flanagan, R.D., 2005. Complementary use of model-free and modelistic methods in the analysis of solid-state kinetics. $J$ Phys Chem B, 109(20), pp.10073-80. pmid:16852219.

Kosaric, N., Vardar-Sukan, F., \& Pieper, H.J., 2001. The Biotechnology of ethanol: Classical and Future Application. In: M. Roehel Ed., Weinheim: Wiley - VCH.

Oudshoorn, A., van der Wielen, L.A.M., \& Straathof, A.J.J., 2012. Desorption of butanol from zeolite material. Biochemical Engineering Journal, 67, pp.167-172.

Saravanan, V., Waijers, A.D., Ziari, M., \& Noordemeer, M.A., 2010. Recovery of 1-butanol from aqueous solutions using zeolite ZSM-5 with a high $\mathrm{Si} / \mathrm{Al}$ ratio; suitability of a column process for industrial applications. Biochemical Engineering Journal, 49, pp.33-39.

Vyazovkin, S., \& Linert, W., 1995. Thermaly induced reactions of solids, isokinetic relationship of nonisothermal decomposition of solids. Chem Phys, 193, pp.109-118. 
НЕИЗОТЕРМИЧЕСКАЯ КИНЕТИКА ДЕСОРБЦИИ ЭТАНОЛА, АБСОРБИРОВАННОГО НА УГЛЕРОДНОМ МОЛЕКУЛЯРНОМ CИTE CMS-3A

Никола С. Йованчич, Боривой К. Аднаджевич, Елена Д. Йованович

Университет в Белграде, Факультет физической химии, г. Белград,

Республика Сербия

ОБЛАСТЬ: химические технологии

ВИД СТАТЬИ: оригинальная научная статья

ЯЗЫК СТАТЬИ: английский

Резюме:

В данной статье описаны проведенные исследования по кинетике десорбции эталона, абсорбированного на углеродном молекулярном сите CMS-3A. Главным источником биоэтанола являются: сахар, кукуруза и лигноцеллюлозные материалы. Выработанный биоэтанол содержит определенное количество воды. Для его очистки используются различные сеперационные методы, которые в настоящий момент еще недостаточно испытаны. Главная проблема очистки биоэтанола заключается в высокой стоимости процедуры и больших затратах энергии на 50\% превышающих производимую биоэтанолом энергию. Селективная адсорбция этанола на цеолите значительно снижает затраты энергии при производстве, но, к сожалению, данный метод требует много времени. В целях улучшения кинетики десорбции могут применятся различные технологии, однако они на сегодняшний день недостаточно испытаны. Одним из самых практичных и наиболее экономичных методов очистки биоэтанола является десорбция этанола на углеродном молекулярном сите, при этом вода остается на поверхности углеродного молекулярного сита. С учетом того, что данный метод недостаточно испытан, необходимо полагаться на знания о кинетике десорбции этанола на цеолитах. Хотя на сегодняшний день опубликовано малое количество научных работ, посвященных исследованиям кинетики десорбции этанола на цеолитах. В данной работе применена неизотермическая термогравиметрическая техника. В ходе исследования была утверждена полная зависимость энергии активации от степени десорбции, а также установлена модель процесса десорбции. Данная модель основана на полной зависимости скорости десорбции от времени и температуры. Благодаря применению данной модели можно повлиять на скорость процесса десорбции и энергию активации с температурой. Математическая модель, описанная в данной работе основана на полной зависимости скорости процесса десорбции и энергии активации от 
температуры. Данная модель также отражает последовательность этапов процесса десорбции. Настоящая модель кинетики процесса десорбции этанола может значительно улучшить технологию производства биоэтанола и уменьшить производственные затраты.

Ключевые слова: зависимость, абсорбенты, молекулярные сита, аналитические модели, модели, цеолиты, CMS-3А, кинетика, этанол, десорбция.

\section{НЕИЗОТЕРМНА КИНЕТИКА ДЕСОРПЦИЈЕ ЕТАНОЛА АДСОРБОВАНОГ НА УГЉЕНИЧНОМ МОЛЕКУЛСКОМ СИTУ CMS-3A}

Никола С. Јованчић, Боривој К. Аднађевић, Јелена Д. Јовановић

Универзитет у Београду, Факултет за физичку хемију,

Београд, Република Србија

ОБЛАСТ: хемијске технологије

ВРСТА ЧЛАНКА: оригинални научни чланак

ЈЕЗИК ЧЛАНКА: енгЛескИ

\section{Сажетак:}

У овом раду проучавана је кинетика десорпције етанола претходно адсорбованог на угљеничном молекулском ситу CMSЗА. Главни извори биоетанола су фрерментабилни шећери, кукуруз и лигноцелулозни отпадни материјал. Произведени биоетанол садржи одређену количину воде, а да би се пречистио користе се разне сепарационе методе које још нису довољно испитане. Главни проблем при пречишћавању биоетанола је висока цена, као и знатан утрошак енергије који представља више од 50\% енергије коју биоетанол производи. Селективна адсорпција етанола са зеолита знатно смањује утрошак енергије при производњи. Нажалост, ова метода је веома спора. Ради побољшања кинетике десорпције користе се различите технике, које нису довољно испитане. Једну од практичнијих и јефотинијих метода која се користи при пречишћавању биоетанола представља десорпција етанола са угљеничног молекулског сита, при чему вода остаје задржана на угљеничном молекулском ситу. Међутим, ова метода није довољно испитана, а ради побољшања производње (брзине производње) потребно је познавати кинетику десорпције етанола са зеолита. Мало је научних радова и литературе који проучавају кинетику десорпције (брзину десорпције) етанола са зеолита За одређивање кинетике десорпције у овом раду је коришћена неизотермна термогравиметријска техника. 
Установљена је комплексна зависност енергије активације од степена десорпције, као и математички модел по којем се десорпција одиграва. Овај модел заснован је на комплексној зависности брзине десорпције од времена и температуре. Због комплексности модела долази до промене брзине десорпције и енергије активације са температуром. Математички модел установљен у овом раду заснива се на комплексној зависности брзине десорпције и енергије активације од температуре и показује на који начин се десорпција одиграва у неколико ступњева. Познавање кинетике процеса десорпције етанола може допринети бољој и економичнијој производњи биоетанола.

Кључне речи: зависност, апсорбенти, молекулска сита, аналитички модели, модели, зеолити, CMS-3А, кинетика, етанол, десорпција.

Paper received on / Дата получения работы / Датум пријема чланка: 24.10.2016. Manuscript corrections submitted on / Дата получения исправленной версии работы / Датум достављања исправки рукописа: 28.11.2016.

Paper accepted for publishing on / Дата окончательного согласования работы / Датум коначног прихватања чланка за објављивање: 30.11.2016.

(C) 2017 The Authors. Published by Vojnotehnički glasnik / Military Technical Courier (www.vtg.mod.gov.rs, Втг.мо.упр.срб). This article is an open access article distributed under the terms and conditions of the Creative Commons Attribution license (http://creativecommons.org/licenses/by/3.0/rs/).

() 2017 Авторы. Опубликовано в «Военно-технический вестник / Vojnotehnički glasnik / Military Technical Courier» (www.vtg.mod.gov.rs, втг.мо.упр.срб). Данная статья в открытом доступе и распространяется в соответствии с лицензией «Creative Commons» (http://creativecommons.org/licenses/by/3.0/rs/).

(C) 2017 Аутори. Објавио Војнотехнички гласник / Vojnotehnički glasnik / Military Technical Courier (www.vtg.mod.gov.rs, втг.мо.упр.срб). Ово је чланак отвореног приступа и дистрибуира се у складу са Creative Commons licencom (http://creativecommons.org/licenses/by/3.0/rs/). 